\title{
How ACRL National Conference sites are selected
}

Questions often arise as to how ACRL ends up hosting a National Conference in a certain city. Below we have attempted to answer the most commonly asked questions.

1) Who decides where to hold the ACRL National Conference? The ACRL Board of Directors approves a site recommended by staff after a lengthy selection process (described below). The ACRL Board then forwards its recommendation to the ALA Executive Board, which has the final authority to approve or not approve a site.

2) What are the procedures for site selection?

a. ACRL staff will identify potential cities for the National Conference that meet the requirements for:

- gond potential for drive-in attendance as well as airline travel;

- meeting and exhibit space;

- the required number of sleeping rooms within a three-block walking distance of the convention center (for the 1997 conference this is 1,400 rooms on the peak night);

- date availability (traditionally, a spring meeting that is scheduled not too close to the ALA Midwinter Meeting or Annual Conference, is before the end of academic institutions' quarters/semesters, and avoids conflicts with major holidays).

b. The ACRL executive director will contact the executive directors of ALA chapters in the states of cities being considered to get initial preliminary support from the chapter for investigating a conference site in its state.

c. ACRL staff will visit potential sites to check out suitability for a National Conference.

d. ACRL staff will contact all ALA and ACRL chapter officers within the state and the contiguous states and regions to the site under consideration to solicit support for a National Conference in the proposed city. ALA policy \#8 requires that chapters be notified in writing about a desired conference site prior to a division submitting the request for approval to the ALA Executive Board. It has not been the practice of the ALA Executive Board to consider approval of conference sites where there is not written acceptance from the state ALA chapters as well as all of those state ALA chapters in the contiguous area.

e. ACRL staff will prepare a document for the ACRL Board's review recommending one or more sites and dates for future conferences.

$f$. The ACRL Board of Directors will review the staff recommendation; if more than one site is proposed, the Board will select one for approval.

g. The ACRL Board will forward its recommendation to the ALA Board for final approval. Typically, the ACRL president and executive director attend the ALA Board meeting to present the request for site approval.

h. Once a site has been sclected, ACRL members in that region will be informed and encouraged to support the holding of the ACRL National Conference there.

3) Why hasn't ACRL held a National Conference in the West in recent years?

As described in the procedures above, ACRL must be welcomed in an area before a conference can be scheduled. Many of the larger western states have strong chapter meetings and/or host ALA meetings and prefer not to have an additional national conference scheduled in their area. Also, since data show that much of the attendance at an ACRL National Conference comes from the immediate region, the selected site must have a density of population in the surrounding area to support a national conference.

4) What should I do if I think having an $A C R L$ conference in my region is a good idea?

Contact your local ALA and ACRL chapters and encourage them to invite ACRL to explore the possibility of having a conference there.

5) Why isn't the conference held in major metropolitan areas like New York, San Francisco, or Atlanta?

ALA practice does not allow a division to hold a national conference in a city that is suitable for hosting the larger ALA Annual Conference. 